\title{
Influence of three bacteria strains on the population dynamics of Tisbe holothuriae (Copepoda, Harpacticoida)
}

\author{
J.-P. Guérin ${ }^{1} \&$ M. Rieper-Kirchner ${ }^{2}$ \\ ${ }^{1}$ Centre d'Océanologie de Marseille (Observatoire des Sciences de l'Univers); Faculté \\ des Sciences de Luminy, Case 901, F-13288 Marseille Cedex 9 - France \\ 2 Biologische Anstalt Helgoland, Meeresstation Helgoland; Postfach 180, D-W-2192 \\ Helgoland, Federal Republic of Germany
}

\begin{abstract}
The influence of three bacteria strains (Helgo 21, NCMB 308 and NCMB 13) on the life cycle of Tisbe holothuriae Humes 1957 was investigated under constant experimental conditions $\left(19-20^{\circ} \mathrm{C}\right.$ and $\left.38 \% \mathrm{~S}\right)$. For each of the first six experiments, females (F1), whose life history was followed, were obtained from a common mother (FO). Experiment $n^{\circ} 7$ was carried out with adult females (F2) obtained during exp. 4. Females were bred in 50-ml dishes and transferred to a fresh container as soon as they produced a new egg-sac. Offspring (F2: exp. 1-6; F3: exp. 7) from successive egg-layings were counted as soon as they moulted into adults. Larval mortality was estimated by enumeration of the adults issuing from a known number of nauplii that had been fed different bacteria strains. Some difficulties arose in obtaining adults with NCMB 13: it appeared to be necessary to provide this first generation with a small quantity of TetraMin (commercial fish food) in order to initiate reproduction and obtain a second generation. However, in exp. 4, F2 adult females fed NCMB 13 became ovigerous and fertile without needing TetraMin. This result is interpreted as denoting an indispensable period of adaptation to the diet, which probably requires important changes at the enzymatic level. One experiment was carried out with Helgo 21; another one with NCMB 308; two with NCMB 13 (with a unique additional meal of TetraMin to allow reproduction), two with $\mathrm{NCMB} 13$ during larval development, then only TetraMin during adult stage, and one with NCMB 13 alone (with females issued from exp. 4). Data obtained regarding longevity, duration of reproduction period, number of egg-sacs and number of adult descendants show an important variability between bacteria strains. Lower results were almost always obtained with Helgo 21 and NCMB 308. An interesting result lies in the maximum number of egg-sacs: low with Helgo 21 and NCMB 308 (5), but very ample with NCMB 13 (11 in one experiment). In experiment 7, carried out with animals bearing a large coefficient of inbreeding $(0.375)$, the results concerning the maximum number of egg-sacs are good (10) as are the mean number of descendants per female (294: the highest number of the seven experiments). These results indicate that genetic factors involved in the reduction of descendants in ageing laboratory cultures can be suppressed to a certain extent by nutritional factors. The poor results obtained with Helgo 21 and NCMB 308 alone must be considered with caution: after a period of adaptation with an alimentary complement, these strains could perhaps permit an interesting production of copepods.
\end{abstract}

\section{INTRODUCTION}

Most species of harpacticoid copepods raised in laboratories are capable of nourishing themselves on a rather large variety of food, be it natural, i.e. microscopic or 
macroscopic algae, alone or in a mixture (Battaglia, 1959; Volkmann-Rocco \& Fava, 1969; Betouhim-El \& Kahan, 1972; Volkmann-Rocco \& Battaglia, 1972; Rothbard, 1976; Guidi, 1984; Uhlig, 1984; Wen Yuh Lee et al., 1985; Chandler, 1986), higher plants, or artificial food. In the latter case, certain species - Tisbe holothuriae in particular - are liable to accept and profit from virtually any substrate: ground dried mussels (Schwenzer, 1985), boiled and shredded grains of wheat (Brand, 1985), fish food (TetraMin, Aqualim), soy flour, hard-boiled eggs, liver, cat food and vegetables, etc. (Gaudy \& Guérin, 1977; Kahan, 1979; Gaudy et al., 1982; Guérin \& Kerambrun, 1982; Cuer, 1983), freshly killed and ground polychaetes (Guidi, 1984). Given the fact, however, that any inert organic substrate is rapidly colonized by bacteria in a marine environment, the copepods are obviously capable of ingesting the bacteria along with the substrate. Thus, VolkmannRocco (1972) considers that $T$. holothuriae has an affinity for macroalgae - of the species Ulva in particular - in a natural environment, but Hicks \& Coull (1983) believe that copepods feed on aggregates of bacteria associated with the decaying tips of algae or detritus pockets. This observation agrees with the results of Brown \& Sibert (1977), who showed that certain harpacticoids assimilate heterotrophically derived carbon at a rate 8 to 10 times higher than autotrophically derived carbon. The problem is determining the actual role of bacteria in the copepods' energy household, and to determine whether this ingestion is passive or whether it is the result of an actual choice. In Prevost Lagoon (near Montpellier, France), Caumette (1987) observed, after a red tide, a dense development of a copepod community of Tisbe sp. which fed on phototrophic bacteria belonging to the genus Thiocapsa. In the laboratory it is a proven fact that bacteria play an important - or even primary - role in the nutrition of harpacticoids. Different authors have shown that a certain number of bacteria strains were entirely sufficient for the development of different species of copepods (Hanaoka, 1973; Itoh, 1973; Rieper, 1978; Ustach, 1982). Rieper (1978), however, observed a great disparity in the results obtained with different bacteria as far as the survival and development rate of a single species of copepod are concerned; a mixture of strains often supplies better results than the use of pure strains.

As far as the choice of food is concerned, it appears that each copepod species has its own type of reaction towards a given food substrate, depending on its chemoreceptive abilities. Certain species of copepods are capable of discriminating between different bacteria strains (Rieper, 1982), or between bacteria and other trophic sources. Thus, Vanden Berghe \& Bergmans (1981) showed that whereas Tisbe holothuriae and $T$. battagliai indiscriminately ingested a mixture of bacteria and Dunaliella tertiolecta, $T$. furcata demonstrated a clear preference for the bacteria under the same conditions. In preference experiments in which $T$. holothuriae was confronted with different bacteria strains, Rieper (1982) showed that certain bacteria strains exert a great attraction, whereas others have a non-attractive character.

Still other experiments indicate that some bacteria may provide indispensable growth factors for copepod culture (Provasoli et al., 1959, 1970).

The experiments described in this article are designed to give an in-depth view of the impact of three pure bacteria strains on the population dynamics of Tisbe holothuriae previously raised on artificial diets (Gaudy \& Guérin, 1977, 1982; Gaudy et al., 1982). 


\section{MATERIAL AND METHODS}

\section{Cultivation techniques and origin of copepods}

The cultivation techniques were those described by Gaudy \& Guérin (1977). The copepods were cultivated in small, air-tight containers $(50 \mathrm{ml})$ at a temperature of 19 to $20^{\circ} \mathrm{C}$, in natural seawater $(\mathrm{S}=38 \%$ ). For each experiment, the females whose descendants were to be studied stem from one single spawn of a recently collected female (FO: Table 1) carrying an egg-sac. Once they reached sexual maturity, ovigerous females

Table 1. Tisbe holothuriae. Diagrammatic scheme of the seven experiments

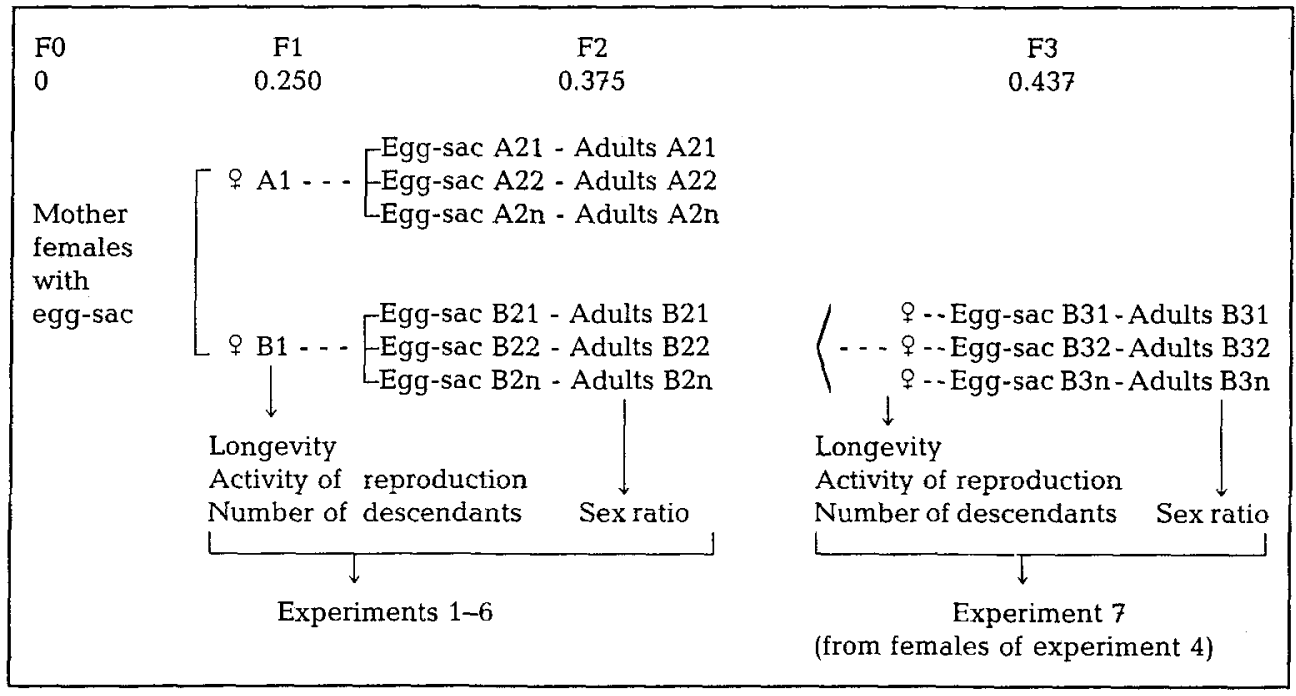

were individually transferred to small glass vessels. Directly following each laying, the females (F1) were transferred to a new vessel, and their descendants raised to sexual maturity. At this point the individuals were counted, marking the termination of the experiment. Experiment 3 does not conform with this pattern as the nauplii issuing from the first five spawns were fixed and counted immediately following their hatching; the nauplii issuing from the following spawns were raised to sexual maturity.

Nature of the bacteria strains; methods of culture; preparation

Bacteria strains NCMB 13 and NCMB 308 were originally obtained from the National Collection of Marine Bacteria, Aberdeen, Scotland. Strain NCMB 13 is a non-pigmented (white) Micrococcus sp., and strain NCMB 308 is a non-motile, non-pigmented Moraxella-like coccobacillus. Helgo 21 is a brown-pigmented strain tentatively identified as Flavobacterium sp., isolated by M. Rieper-Kirchner from a sediment sample taken near the island of Helgoland, southern North Sea. All strains were maintained on ZoBell 2216E standard yeast extract - peptone agar medium for marine bacteria. 
Dried bacteria particles to be used as food for Tisbe were prepared as follows (Rieper, 1982): material from an agar culture was inoculated into liquid 2216E medium without agar and incubated at $20^{\circ} \mathrm{C}$ until a strong turbidity was observed. The material was then centrifuged, washed twice with autoclaved seawater and centrifuged again. The pellet was then dried $3-4 \mathrm{~h}$ at $55-65^{\circ} \mathrm{C}$ and ground to small particles no larger than $1 \mathrm{~mm}^{3}$. These bacteria particles were stored in a dry place at room temperature $\left(20-22^{\circ} \mathrm{C}\right)$ until use.

\section{Experiments}

Three series of experiments were carried out. The first one consisted in comparing the influence of each of the bacteria strains, Helgo 21 (exp. 1), NCMB 308 (exp. 2), and NCMB 13 (exp. 3). From the population issuing from one spawn, one ovigerous female per $50-\mathrm{ml}$ container was isolated and fed exclusively with one of the three bacteria strains. These females were removed immediately following laying, and their descendants - which constitute the F1-generation - continued receiving the same food. It was easy to obtain ovigerous females - even in small quantities - with Helgo 21 and NCMB 308. Experiments using the NCMB 13-strain, however, proved to be more problematic, as development always came to a halt before the laying, or after abortive sacs were formed. After several unsuccessful attempts, mature adults were obtained following an accidental contamination with TetraMin; it seemed interesting to carry on with the experiment on NCMB 13, feeding the F1-individuals with TetraMin in the adult phase.

During the second series of experiments, three new batches of females were nourished either with the NCMB 13-strain exclusively (exp. 4) (except for a TetraMin "meal"), or at first with bacteria during larval development, and then - once sexually mature - solely with TetraMin (exp. 5 and 6). It should be mentioned that this latter product is a food for aquarium fish and has already been used for raising polychaetes (Guérin, 1971, 1973) and Tisbe holothuriae (Gaudy \& Guérin, 1977, 1982).

Finally, the third series (exp. 7) was carried out on ovigerous females issuing from one of the F2-females from experiment 4 . It is important to note that in this case an F3generation originating from two generations which had been fed exclusively with NCMB 13 was used in the experiment. Given the fact that mating always occurred between individuals of the same spawn, the different inbreeding coefficients can be calculated with the equations given by Stansfield (1981), F1 $=0.250, F 2=0.375$ (these two values agree with data of Battaglia, 1970), F3 $=0.437$.

It appears that the number of $\mathrm{F} 1$-females whose vital cycles were studied varied slightly from one experiment to another. This is due, on the one hand, to the limited quantity of bacteria available, and on the other hand to the frequently small number of females that became ovigerous in one spawn.

It was not practical to count the number of nauplii (except in exp. 3); we merely counted the adults obtained. It is difficult to say whether the fluctuations in the number of individuals from successive spawns can be related to variations in fertility, as a certain larval mortality occurred between the hatching of the eggs and the point of sexual maturity. Assuming that this mortality is relatively constant throughout the biological cycle, the fecundity can however be deduced from the larval mortality rate.

In this respect, four groups of three batches of 25 nauplii from 12 different females were raised simultaneously to determine the mortality rate during the phase extending 
from hatching to the fecund adult stage. Each group was fed with a different bacteria strain, except for the two groups which were nourished with NCMB 13 - one group was given this bacteria strain alone, whereas the other received a single meal of TetraMin in addition. The adults from the second generation were fixed and counted as soon as their first descendants hatched. This experiment also revealed a new value for the time lapse necessary for obtaining a new generation.

\section{RESULTS}

The first result pertains to the terms and conditions of obtaining fertile females with the NCMB 13-strain. These factors are different according to whether they concern the first or the second generation nourished with these bacteria.

The F1-generation is the first generation yielded by the original population of mother-females that received bacteria alone: the 8 attempts made under these conditions never yielded fertile females, although some formed ar egg-sac. Providing this generation with a small quantity of TetraMin seemed indispensable in order to induce reproduction. Although this problem has not yet been studied in depth, it appears that the development of the adult stage is frozen at sexual maturity, and that the individuals do not mate as long as they are fed only bacteria. Yet if a small amount of TetraMin is given, the block disappears and pairing can be observed soon after; 24 to $36 \mathrm{~h}$ later, ovigerous females appear whose eggs develop. It would seem that TetraMin supplies an essential substance which the animals are apparently not capable of synthesizing. For the moment, it is impossible to tell whether the block afflicts the females, the males, or both sexes. It must yet be determined which moment is the most favorable for supplying the TetraMin, and what is the minimum indispensable quantity.

The results yielded by the descendants of the F1 - in other words the F2 - oblige us to modify this analysis. As a matter of fact, in contrast to their mother, the F2-females produced by experiment 4 became ovigerous and fertile without having needed TetraMin. The block observed in the first generation does not exist in the second generation. These F2-females in turn yielded fertile descendants without the aid of TetraMin: this is the case in 7 females from experiment 7 issuing from a single spawn from experiment 4 ; as will be seen, they showed none of the expected signs of degeneration.

An overall view of the other results appears in Table 2 which calls for some comments.

\section{Longevity of the F1-females (exp. 1-6) and F2 females (exp. 7)}

Longevity is calculated starting from the hatching of the egg $g_{i}$ it thus includes the larval phase but not the embryonic phase. The fluctuations in longevity in the experiments are remarkable, but not significant $(F=3.29$ with $F 0.05=3.56$ ). The values obtained from the three experiments of the first series are rather dissimilar: the Helgo 21 values are low (25.3 days); the NCMB 308 values are higher (32.2 days), as are also the NCMB 13 values (44.6 days). In this latter case (exp. 3), the females proved to have a high longevity: two of them lived for 51 days, another lived for 47 days. In the second series, the average longevity did not vary much from one experiment to another; it ranged from 28.3 days (exp. 4) to 29.4 days (exp. 6) to 31.4 days (exp. 5), respectively. These values lie 
Table 2. Tisbe holothuriae. Population measurements ( \pm standard deviation) from the different experiments; m: mean

\begin{tabular}{|c|c|c|c|c|c|c|c|}
\hline Experiment & 1 & 2 & 3 & 4 & 5 & 6 & 7 \\
\hline $\begin{array}{l}\text { Bacteria } \\
\text { strain }\end{array}$ & Helgo 21 & NCMB 308 & NCMB 13 & NCMB 13 & $\begin{array}{l}\text { NCMB } 13 \\
\text { and then } \\
\text { TetraMin }\end{array}$ & $\begin{array}{l}\text { NCMB } 13 \\
\text { and then } \\
\text { TetraMin }\end{array}$ & NCMB 13 \\
\hline $\begin{array}{l}\text { Number of } \\
\text { mother } \\
\text { females }\end{array}$ & 6 & 11 & 5 & 12 & 10 & 10 & 7 \\
\hline $\begin{array}{l}\text { Average } \\
\text { longevity } \\
\text { (days) }\end{array}$ & $\begin{array}{r}25.3 \\
\pm \quad 3.20\end{array}$ & $\begin{array}{r}32.2 \\
\pm \quad 6.26\end{array}$ & $\begin{aligned} & 44.6 \\
\pm & 11.39\end{aligned}$ & $\begin{array}{r}28.3 \\
+\quad 8.54\end{array}$ & $\begin{array}{r}31.4 \\
\pm \quad 6.13\end{array}$ & $\begin{array}{r}29.4 \\
\pm \quad 5.41\end{array}$ & $\begin{array}{r}42.1 \\
\pm \quad 5.19\end{array}$ \\
\hline $\begin{array}{l}\text { Duration (m) } \\
\text { reproductive } \\
\text { period (days) }\end{array}$ & $\begin{array}{l}10 \\
\pm \quad 3.32\end{array}$ & $\begin{array}{ll} & 9.3 \\
\pm & 1.89\end{array}$ & $\begin{array}{r}21 \\
\pm \quad 8.07\end{array}$ & $\begin{aligned} & 12.6 \\
& \pm \quad 7.30\end{aligned}$ & $\begin{array}{c}18.6 \\
\pm \quad 7.22\end{array}$ & $\begin{array}{r}13.5 \\
\pm \quad 3.82\end{array}$ & $\begin{array}{c}19.4 \\
\pm \quad 2.61\end{array}$ \\
\hline $\begin{array}{l}\text { Number }(\mathrm{m}) \\
\text { of sacs }\end{array}$ & $\begin{array}{ll} & 2.8 \\
\pm & 1.34\end{array}$ & $\begin{array}{ll} & 3.2 \\
\pm & 0.83\end{array}$ & $\begin{array}{ll} & 8.6 \\
\pm & 2.24\end{array}$ & $\begin{array}{ll} & 4.4 \\
\pm & 2.72\end{array}$ & $\begin{array}{ll} & 5.3 \\
\pm & 1.85\end{array}$ & $\begin{array}{ll} & 6.2 \\
+\quad 1.33\end{array}$ & $\begin{array}{l}8 \\
\pm \quad 1.41\end{array}$ \\
\hline $\begin{array}{l}\text { Maximum } \\
\text { number of sacs }\end{array}$ & 5 & 5 & 11 & 9 & 8 & 8 & 10 \\
\hline $\begin{array}{l}\text { Adult }(\mathrm{m}) \\
\text { descendants }\end{array}$ & $\begin{aligned} & 68.6 \\
\pm & 52.92\end{aligned}$ & $\begin{aligned} & 69.7 \\
\pm & 47.31\end{aligned}$ & $\begin{array}{r}186.8^{\circ} \\
\pm \quad 75.60\end{array}$ & $\begin{aligned} & 160.5 \\
\pm & 122.75\end{aligned}$ & $\begin{array}{r}231.2 \\
\pm 85.45\end{array}$ & $\begin{array}{c}245.8 \\
\pm 66.26\end{array}$ & $\begin{aligned} & 294 \\
\pm & 111.54\end{aligned}$ \\
\hline $\begin{array}{l}\text { Descendants } \\
\text { per sac }(\mathrm{m})\end{array}$ & $\begin{array}{l}24.5 \\
\pm 18.84\end{array}$ & $\begin{aligned} & 21.8 \\
\pm & 16.48\end{aligned}$ & $\begin{aligned} & 21.7 \\
\pm & 12.70\end{aligned}$ & $\begin{aligned} & 36.5 \\
+ & 20.84\end{aligned}$ & $\begin{aligned} & 43.6 \\
\pm & 24.34\end{aligned}$ & $\begin{aligned} & 39.6 \\
+ & 13.80\end{aligned}$ & $\begin{aligned} & 36.7 \\
\pm & 19.31\end{aligned}$ \\
\hline Sex ratio & $\begin{array}{r}0.40 \\
\pm \quad 0.19\end{array}$ & $\begin{array}{r}0.20 \\
\pm \quad 0.17\end{array}$ & $\cdot$ & $\begin{array}{r}0.52 \\
\pm \quad 0.24\end{array}$ & $\begin{array}{r}0.51 \\
\pm \quad 0.22\end{array}$ & $\begin{array}{r}0.38 \\
\pm \quad 0.22\end{array}$ & $\begin{array}{r}0.45 \\
\pm \quad 0.18\end{array}$ \\
\hline
\end{tabular}

between the Helgo 21 and the NCMB 308 values. Whether the animals received bacteria (exp. 4) or TetraMin (exp. 5 and 6) during their fertile life has apparently no relevance here.

The animals from experiment 7 however showed a high longevity of 42.1 days, which resembles the one observed in experiment 3 under the same trophic conditions (except for a TetraMin meal). It must be stated that the longevity of the animals from experiment 4 is clearly lower.

\section{Reproductive activity}

The reproductive period, comprising the time from the first to the last egg-sac formation, varies from 9.3 days to 21 days in all the experiments (extreme values). The lowest values were observed with Helgo 21 and NCMB 308 (10 and 9.3 days, respectively), both of which brought forth the smallest amount of egg sacs (2.8 and 3.2, respectively). The two highest values were observed with NCMB 13 (exp. 3 and 7:21 and 19.4 days, respectively), and they produced on average the highest number of egg-sacs (8.6 and 8, respectively). Experiment 4-also using NCMB 13 - presents a low value for 
the reproductive period and also an inconsistent average number of sacs: 4.4. The two experiments in which NCMB 13 and TetraMin were given successively differ greatly as far as reproductive periods are concerned (18.6 and 13.5 days, respectively), whereas the number of egg-sacs are rather similar (5.3 and 6.2).

It is interesting to note the maximum number of egg-sacs produced by one and the same female during a given experiment. This number was low with Helgo 21 and NCMB 308: 5 in each case. In experiment 5 and 6 (NCMB 13 and then TetraMin) it climbs to 8. Finally, the highest values were observed with NCMB 13: 9 layings for 2 females from experiment 4 , and 10 for a female from experiment 7 ( 2 other females furnished 9 spawns) and 11 for a female from experiment 3 ( 2 others furnished 10 ).

In other words, the most productive females from experiments 3,4 , and 7 furnished another 13 spawns while the 2 most productive females from experiments 5 and 6 had ceased their reproductive activity: the switch of bacteria diet to TetraMin was not favorable to the production of egg-sacs.

\section{Numbers of adult descendants of the F1 females (exp. 1-6)} and F2 females (exp. 7)

This data yields information on the efficiency of the alimentary diets. The average numbers of descendants per female range from 68.6 (exp. 1) and 69.7 (exp. 2), to four times those values (294 for experiment 7 ). The average number of descendants in experiment 7 is clearly higher than the one obtained in the experiments $3(186.8)$ and 4 (160.5) under similar nutritional conditions. Experiments 5 and 6 show similarly high values (231.2 and 245.8, respectively).

A variance analysis confirms that the fertility differences between experiments are significant $(F=8.46$ with $F 0.05=3.56)$, but this indication loses some of its value considering the variability observed between the three experiments in which NCMB 13 was administered.

The number of adults yielded by each laying also varied to a great extent within one experiment as well as between experiments. It appears that the most productive spawns are rather late in a certain number of cases: spawn $n^{\circ} 4$ for experiments 1 and 2 , spawn $n^{\circ}$ 6 for experiment 4 , and spawn $n^{\circ} 7$ for experiment 6 (Fig. 1). Actually, at this moment and in all these cases, a certain amount of somewhat unproductive females died, which raised the average productivity values.

The average fertility (expressed as number of adult descendants, except in exp. 3) is not influenced by the length of the reproductive period observed during experiments 3 and 7 , and is expressed by a greater production of egg-sacs. When considering the experiments on the whole, it appears that the average number of descendants per sac is identical in experiment 2 ( 21.8 for a maximum of 5 egg-sacs) and experiment 3 (also 21.7 for a maximum of $11 \mathrm{egg}$-sacs). Yet this result is slightly distorted, as during experiment 3 the count was carried out partly on nauplii (see "Materials and Methods").

Experiments 5 and 6 - each with a maximum of $8 \mathrm{egg}$-sacs - have a higher average number of descendants per sac (43.6 and 39.6) than experiments 4 and 7 ( 36.5 and 36.7, with max. 9 and 10 sacs, respectively). In experiment 4 , three females furnished practically identical amounts of descendants: 356 in 8 layings for the one, 353 in 6 layings for another, and 349 in 9 layings for the third. These 23 layings represent $43.3 \%$ of the total 

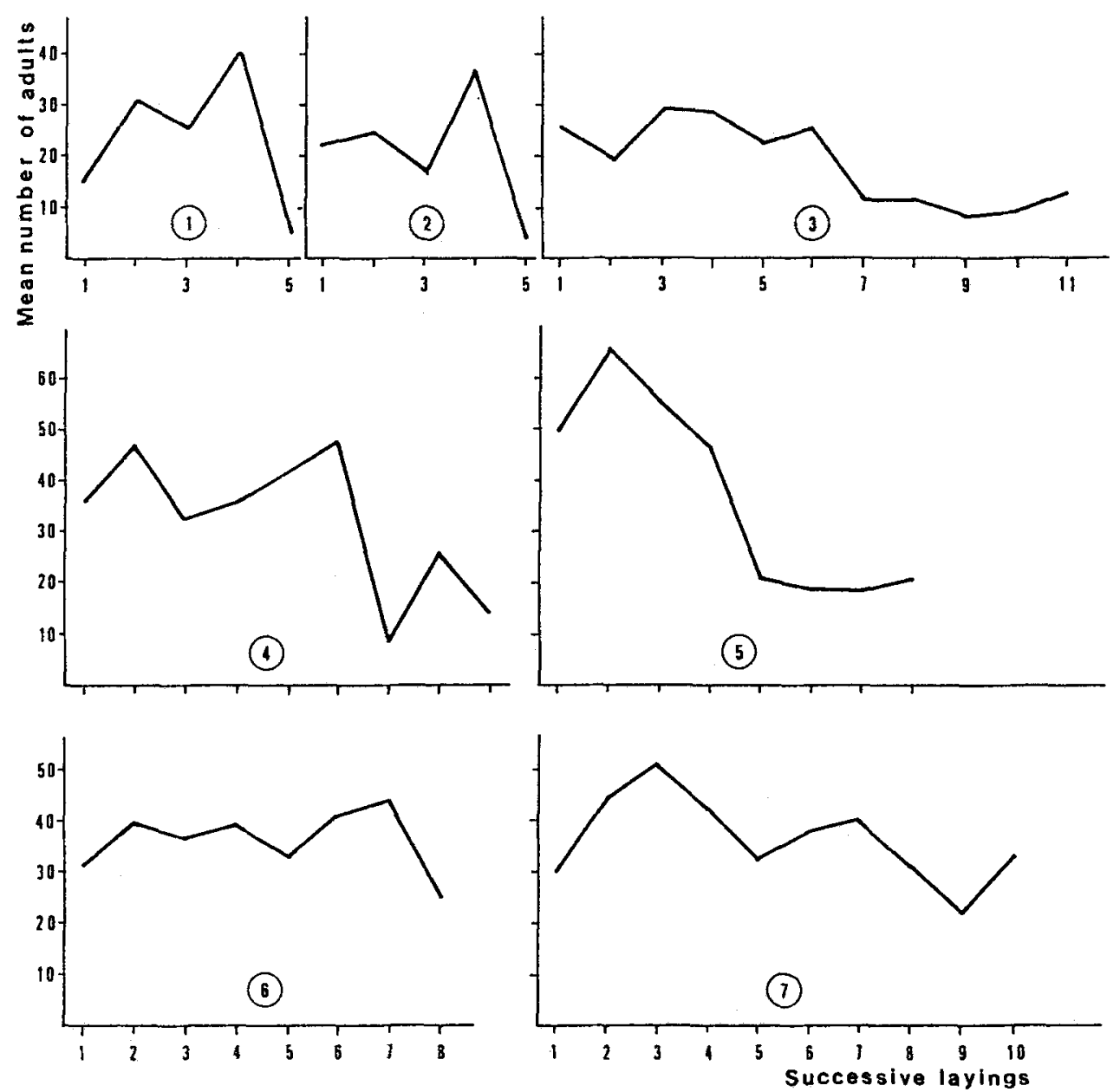

Fig. 1. Tisbe holothuriae. Mean number of adults appearing in successive layings. (In exp. 3, data concern nauplii and not adults for the first five layings)

number of layings, and their descendants represent $55 \%$ of the total number of descendants obtained during the experiment.

The observed minimum and maximum numbers of adult descendants stemming from one female during the different experiments vary tremendously. It is not uninteresting to note that the maximum furnished by one female from experiment 1 (137) is nearly identical to the minimum of another female from experiment 6 (134). In experiments 4 through 7 , a certain number of females yielded over 300 descendants: 3 out of 12 females in experiment 4,2 out of 10 females in both experiments 5 and 6 , and 4 females in experiment 7 . 


\section{Duration of development and larval mortality}

Duration of development and larval mortality were established from the rearing of 3 sets of 25 nauplii fed on each bacteria strain, and 3 sets fed on NCMB 13 with one meal of TetraMin (Table 3).

The average duration of development - time lapse separating the hatching of the egg and the appearance of the following generation of nauplii - and the mortality rate varied

Table 3. Tisbe holothuriae. The percentage of larval mortality and duration of development of 3 sets of 25 nauplii fed three different bacteria strains

\begin{tabular}{|c|c|c|c|c|c|c|}
\hline \multirow{2}{*}{$\begin{array}{l}\text { Bacteria } \\
\text { strain }\end{array}$} & \multicolumn{2}{|c|}{ Adults } & \multirow[b]{2}{*}{ Total } & \multirow{2}{*}{$\begin{array}{c}\text { Mortality } \\
(\%)\end{array}$} & \multicolumn{2}{|c|}{ Minimum generation time } \\
\hline & $\delta$ & $q$ & & & Days & Mean \\
\hline & 18 & 6 & 24 & 4 & 12.5 & \\
\hline \multirow[t]{3}{*}{ Helgo 21} & 7 & 12 & 19 & 24 & 14 & 12.8 \\
\hline & 19 & 3 & 22 & 12 & 12 & \\
\hline & $\Sigma 44$ & 21 & 65 & $k-13.33$ & & \\
\hline \multirow{4}{*}{ NCMB 308} & 21 & 3 & 24 & 4 & 12 & \\
\hline & 21 & 4 & 25 & 0 & 11 & 11.5 \\
\hline & 18 & 4 & 22 & 12 & 11.5 & \\
\hline & $\Sigma 60$ & 11 & 71 & $\mathrm{k}-5.33$ & & \\
\hline NCMB 13 & 12 & 0 & 12 & 52 & - & \\
\hline (Without & 13 & 0 & 13 & 48 & - & \\
\hline \multirow[t]{2}{*}{ Tetramin) } & 6 & 2 & 8 & 68 & - & \\
\hline & $\Sigma 31$ & 2 & 33 & $k-56.00$ & & \\
\hline NCMB 13 & 10 & 7 & 17 & 32 & 14.5 & \\
\hline (With & 16 & 6 & 22 & 12 & 14 & 14.33 \\
\hline \multirow[t]{2}{*}{ Tetramin) } & 11 & 9 & 20 & 20 & 14.5 & \\
\hline & $\Sigma 37$ & 22 & 59 & $\mathrm{k}=21.33$ & & \\
\hline
\end{tabular}

according to the administered bacteria strain. Variations in duration of development were not negligible: the lowest values occurred with NCMB 308: 11.5 days, the highest with NCMB 13 and TetraMin (14.33). The mortality rate, low with NCMB 308 (0.05), was very high with NCMB 13 without TetraMin (0.56); it is better with NCMB 13 and TetraMin (0.21). These values were used for calculating the parameters of population dynamics presented in Table 5.

\section{Sex ratio}

The sex ratio (expressed as ratio of females/total adults) varied according to two factors: food and the age of the females.

Variations according to the type of food. Table 2, showing the data for the sex ratio of the total descendants, reveals that the values are low for all 
experiments, except for experiments 4 and 5 in which the proportion of females is slightly higher than that of males. NCMB 308 yielded only a very small number of females. The values from experiments 1 and 6 are very similar, although with different food, whereas the values are very different in experiments 5 and 6 with the same food offered. This obvious difference makes all statistical comparison superfluous.

When focussing on the sex ratio of the descendants of each female within the different experiments instead of considering the overall descendants, it appears that the values are always greatly dispersed. Thus, during experiment 2 , where the average value is 0.2 , very low values, 0.03 and 0.08 , and a high value, 0.44 , were observed. A dispersion of the same magnitude is observed in experiments 4 through 7 , the greatest difference being due to the females from experiment 6 where the extreme values are 0.16 and 0.76 for an average of 0.38 .

Variations according to the age of the females. Figure 2 illustrates the variations in the course of time, and was based upon the average values of the sex ratio of the adult population issuing from successive layings. It appears that the sex ratio variation is slight from one laying to another in certain experiments: $1,2,6$ (except for the last laying), and 7 to a lesser extent, during which the descendants of one single laying
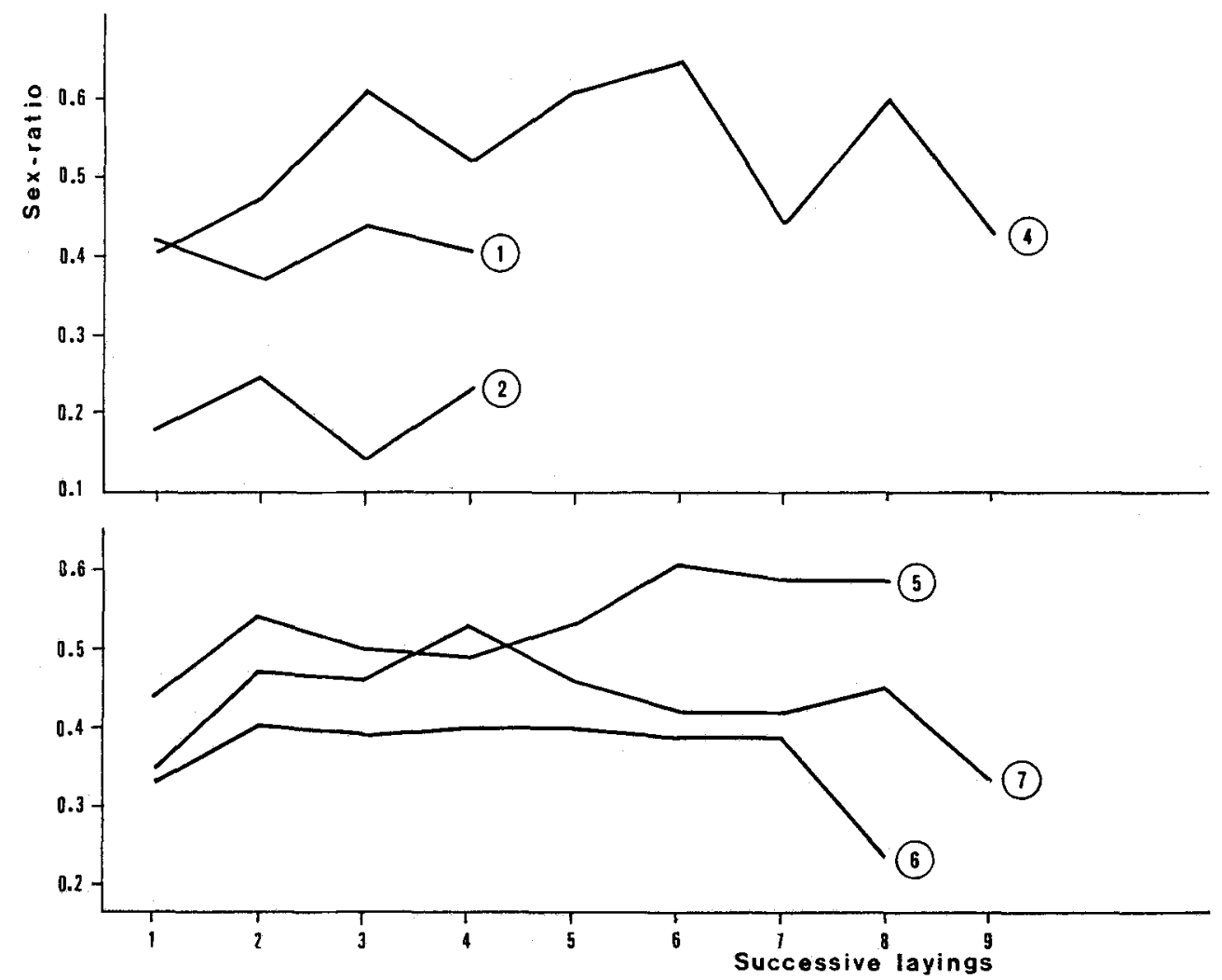

Fig. 2. Tisbe holothuriae. Mean sex ratio (0 number/total number of adults) in successive layings. (In exp. 1 and 2 , laying $n^{\circ} 5$ was omitted because the number of adults obtained was too low and not significant. Exp. 3 was entirely omitted) 
present a sex ratio slightly greater than 0.5 . Experiments 4 and 5 show the highest variability; however, no fluctuation in either direction appears during the course of time.

Finally, when comparing the sex ratio of the descendants of the individual females, great variations are apparent from one female to another. Certain females produce practically only males (exp. 2: 167 males out of 173 descendants of a mother female); the contrary situation is more exceptional; the highest sex ratio $(0.76)$ was observed in the descendants of a female from experiment 6 (204 males, 155 females).

\section{Population growth parameters}

The results concerning the number of male or female descendants produced successively, the chronology of larval development, and the reproduction period yield precise population growth parameters for each bacteria strain offered as food (Table 4).

Table 4. Tisbe holothuriae. Population growth parameters. $\mathrm{R}_{\mathrm{o}}$ : net reproductive rate; $\mathrm{T}$ : mean generation time; $\mathrm{rm}$ : intrinsic rate of natural increase

\begin{tabular}{|c|c|c|c|c|c|c|}
\hline Exp. & 1 & 2 & 4 & 5 & 6 & 7 \\
\hline $\begin{array}{l}\text { Bacteria } \\
\text { strain }\end{array}$ & Helgo 21 & NCMB 308 & NCMB 13 & $\begin{array}{l}\text { NCMB } 13 \\
\text { and then } \\
\text { TetraMin }\end{array}$ & $\begin{array}{l}\text { NCMB } 13 \\
\text { and then } \\
\text { TetraMin }\end{array}$ & NCMB 13 \\
\hline$R_{o}$ & 27.67 & 14.09 & 82.8 & 117.8 & 94.22 & 132.0 \\
\hline$T$ & 18.25 & 17.62 & 19.57 & 18.17 & 19.67 & 20.72 \\
\hline $\mathrm{rm}$ & 0.182 & 0.150 & 0.266 & 0.263 & 0.231 & 0.236 \\
\hline
\end{tabular}

The net reproduction rate, $R_{0}$, the factor by which the female population is multiplied from one generation to the next, is calculated for each experimental batch by calculating the Fn+1-females/Fn-mother female ratio. It appears that the Helgo 21 and NCMB 308 strains yield very low values, which complies with the rather high mortality rate with Helgo 21 and especially with the somewhat mediocre production of females receiving NCMB 308. When administering NCMB 13 (alone, or followed by TetraMin) the values are clearly higher, but with considerable variations from one experiment to another. It seems advisable to emphasize the fact that the best results are obtained - in this case as well - in experiment 7 , even though a decrease in the production of females was to be expected. Unfortunately, this fact can only be stated $i$ it is impossible to draw any conclusion from it.

If several successive layings appear, the average generation time $\mathrm{T}$ can be defined with a rather good approximation by the formula:

$$
\mathrm{T}=\varepsilon \mathrm{x} \cdot \mathrm{ux} / \varepsilon \mathrm{ux}
$$

$x$ being the age (in days) of the females at the moment of the nauplii production, and $u x$ being the number of female nauplii at the day $x$ (Dublin \& Lotka, 1925). In this study, ux was not estimated from the day of the hatching but could be derived from the number of females $\mathrm{fx}$ issued from $\mathrm{ux}$, taking into account the constant larval mortality rate $\mathrm{k}$, 
established from another source (Table 3). In practice the formula for calculating $T$ becomes:

$$
\mathrm{T}=\frac{\varepsilon \mathrm{x} \cdot \mathrm{fx}}{\varepsilon \mathrm{fx}}
$$

The average generation times appear rather different from one experiment to another, although the variation interval is rather low. The lowest average time is obtained using NCMB 308 (17.62). With NCMB 13 the values are dissimilar: experiments 5 and 6 , which are absolutely comparable, reveal somewhat different average times (18.17 and 19.67); experiment 7 (second generation to be fed with NCMB 13 exclusively) has the highest average time. The similarity of the generation time of experiment 4 (19.57), where NCMB 13 was administered during the entire adult life, and that of experiment 5 (19.67) using TetraMin during the adult stage, is rather surprising.

The specific growth rate is calculated using the formula:

$$
\mathrm{rm}=\frac{\operatorname{Ln} \mathrm{R}_{\mathrm{o}}}{\mathrm{T}}
$$

This parameter, which expresses the species' development potential per time unit, allows comparisons between species with different cycles. The examination of Table 2 reveals low values with Helgo 21 and especially NCMB 308. In the experiments using NCMB 13, however, there is a rather remarkable homogeneity, whether or not the bacteria were replaced by Tetramin once the adults were obtained.

\section{DISCUSSION}

It is interesting to compare the results obtained 'when offering Tisbe holothuriae bacteria as food with those obtained from previous experiments with $T$. holothuriae and other copepods using artificial food (Gaudy \& Guérin, 1977, and Gaudy et al., 1982; Hoppenheit, 1975a, b, 1976; Uhlig \& Schwenzer, 1979; Uhlig \& Sahling, 1981; Lopez, 1982; Uhlig, 1983, 1984; Schwenzer, 1985); and bacteria (Itoh, 1973; Hanaoka, 1973; Rieper, 1978, 1982,1984; Ustach, 1982). It is not only interesting but also essential to compare these results with those obtained previously with $T$. holothuriae (Table 5).

In the first place, it must be stated that the bacteria used as trophic source had

\begin{tabular}{|c|c|c|c|c|}
\hline Authors & Foods & $R_{0}$ & $\mathrm{~T}$ & $\mathrm{rm}$ \\
\hline $\begin{array}{l}\text { Gaudy \& Guérin (1977) } \\
\left(\mathrm{T}=19-20^{\circ} \mathrm{C} ; 38 \% \mathrm{~S}\right)\end{array}$ & $\begin{array}{l}\text { TetraMin } \\
\text { Renutryl } \\
\text { A. Bioter }\end{array}$ & $\begin{array}{r}86.4 \\
120.1 \\
180.8\end{array}$ & $\begin{array}{l}17.04 \\
16.02 \\
17.20\end{array}$ & $\begin{array}{l}0.260 \\
0.298 \\
0.301\end{array}$ \\
\hline Gaudy et al. (1982) & $\begin{array}{l}\text { Germalyne } \\
\text { Renutryl }\end{array}$ & $\begin{array}{r}46.7 \\
139.6\end{array}$ & $\begin{array}{l}15.31 \\
15.76\end{array}$ & $\begin{array}{l}0.251 \\
0.313\end{array}$ \\
\hline Cuer (1983) & Bacteria & 17.6 & 10.96 & 0.262 \\
\hline $\begin{array}{l}\text { Schwenzer (1985) } \\
\text { - Values calculated usin }\end{array}$ & $\begin{array}{l}\text { Mussel meal } \\
\text { e method of } G\end{array}$ & $\begin{array}{l}128.2 \\
\text { Guér }\end{array}$ & $18.85^{*}$ & $0.2575^{\circ}$ \\
\hline
\end{tabular}

Table 5. Tisbe holothuriae. Literature on population dynamics data 
previously been dried in a hot-air oven (Rieper, 1982). This technique stabilizes the chemical composition, but also creates artificial conditions. This treatment might even influence the gustatory qualities of the-bacteria strains as far as the copepods are concerned. A highly prized live strain could thus be modified by drying to the point of becoming neutral or even revolting. Kobayashi \& Kurata (1978) showed that drying Rhodopseudomonas capsulata cells at $130^{\circ} \mathrm{C}$ alters their chemical composition with the result that they no longer have any favorable effect on chicken eggs, as opposed to fresh cells.

One of the most interesting results obtained with the three experimental strains in these tests is the method of obtaining fertile adults from young individuals fed with bacteria: only two out of the three tested strains permit a complete development cycle in the first generation. The fact that a strain may impede development is not surprising in itself, especially since Rieper (1982) showed that NCMB 13 does not exert any trophic attraction on $T$. holothuriae, as opposed to Helgo 21 and NCMB 308. The fact that this block can be eliminated by furnishing a small amount of TetraMin towards the end of the development is, however, very interesting from a biological point of view.

The total absence of a blocking process during the development of the F2-generation (exp. 7) actually shows that it had acquired the capacity to make better use of the NCMB 13 strain than the preceding generation: it was able to develop a physiological response to new trophic conditions. This implies that a new metabolic channel - until then unfunctional but nevertheless inscribed in the individual's genome - had been opened. Given the fact that this adaption takes two generations to develop, it appears that the genetic selection took place in the gametes produced by the generation which needed a TetraMin meal in order to reproduce. So this selection is a completely different process in terms of magnitude and of its mechanisms - from the modifications revealed by Guérin \& Kerambrun (1982) by administering 8 different meals to $T$. holothuriae: in this latter case the first generation's enzymatic activity modifications were adaptations of a somatic nature.

The other results do not appear to allow an overall synthesis, as the different parameters of the study are very variable: it is thus necessary to evaluate each parameter separately.

Lon g e vity. In most cases, the average longevity obtained with the three bacteria strains ranges between the maximum and minimum values observed by Gaudy \& Guérin (1977) who tested three artificial diets, that is to say 33.4 days with TetraMin and 23.6 days with Renutryl. Using bacteria as food, however, two values range far beyond the maximum observed by these authors: 44.6 days (exp. 3) and 42.1 days (exp. 7), respectively, which increase the longevity by 10 days. Cuer (1983), on the contrary, obtained the lowest longevity values for the adult stage (12 days to which 12 days of larval development must be added) using a bacteria diet. In the present case, the use of bacteria tends to increase the animals' potential life-span classically observed when the breeding temperature is reduced; it is, however, difficult to determine - especially considering the variability - whether the bacteria increase the life-span by reducing the metabolism, or whether it is because they represent a diet more similar to the natural one. This latter argument is probably irrelevant in the case of NCMB 13 , which is certainly no more attractive in nature than in the laboratory - except if, as we already mentioned, the drying modifies its gustatory qualities. The longevity of other species of the genus Tisbe 
is often clearly superior to the values observed in the present study. Tisbe gracilis can be stated as an example, its average life span being 52.7 days (Battaglia, 1957), but also $T$. persimilis (62.5 days), and especially T. reluctans (81.4 days: Volkmann-Rocco \& Fava, 1969). It is difficult to determine whether these longevities are of genetic origin - in other words a constant for a given species - or whether they are the consequence of an algal diet.

In the past, Rieper $(1978,1984)$ showed that $T$. holothuriae could present very variable generation times depending on the bacteria strain used as food. Thus, at $18^{\circ} \mathrm{C}$ it takes 13.8 days from nauplius to nauplius when $T$. holothuriae is fed with Alteromonas sp.; with NCMB 308 the generation time climbs to 15.5 days (which is slightly higher than the values obtained in the present case) at $18^{\circ} \mathrm{C}$ and $28-30 \% \mathrm{~S}$. With Pseudomonas fluorescens this time lapse is 20 days. With Chromatium sp., it was 17 days (Rieper, 1984). With Rhodospeudomonas palustris the vital cycle could not be completed.

Larval mortality increased from NCMB 308 to Helgo 21, further with NCMB 13 with TetraMin and finally with NCMB 13 alone (in the Fl-generation), but this does not appear as a good test for the trophic quality of the bacteria, which is absolutely normal as the needs and demands are not the same throughout the vital cycle. It must be stated that the larval mortality rates represent extreme values for the values observed previously (Gaudy \& Guérin, 1977). The mortality obtained with NCMB 308 is lower than any value quoted in the literature (see Uhlig, 1983, 1984); the mortality observed with NCMB 13 alone in the $\mathrm{F} 1$-generation reaches, on the contrary, very high levels.

As far as the average number of egg-sacs produced by the F1 females is concerned, the values obtained from the strains fed with Helgo 21 and NCMB 308 are clearly inferior to all those quoted previously (see Table 3, Gaudy \& Guérin, 1977). The average values obtained during experiment 3 and 7 ( 8.6 and 8 , respectively) are, on the other hand, close to the results obtained by Johnson \& Olson (1948) with.T. furcata. As far as the maximum number of egg-sacs produced by one female during the different previous experiments is concerned (Gaudy \& Guérin, 1977; Gaudy et al., 1982), the number of 8 was only rarely reached and never exceeded, although several hundred $T$. holothuriae females had been observed individually. Cuer (1983), however, obtained 9 spawns from a $T$. holothuriae female fed with milt, while the bacteria used by this author allow a maximum of only 4 layings. The NCMB 13 strain - which allowed the obtainment of up to 11 eggs-sacs - thus has a singularly original effect on the production of eggs. It is an interesting reminder that Johnson \& Olson (1948) obtained up to 12 layings from $T$. furcata.

If, however, one considers the average number of individuals yielded by the total layings, the values obtained in experiments 4 and 7 are absolutely comparable to those of Volkmann-Rocco \& Battaglia (1972) (from 159.6 with $T$. clodiensis to 320.2 with $T$. dozhanskii), but they are nevertheless far lower than the values obtained previously (Gaudy \& Guérin, 1977) with TetraMin, Renutryl, and especially with the Bioter food. The bacteria strains tested thus furnish a production potential comparable to that of algae, but inferior to that of artificial diets.

In order to compare the production capacity of a species or of a lineage, it is indispensable to take into account the sex ratio and the delay necessary for obtaining a generation. As far as the sex ratio is concerned, Lang (1948) and Volkmann-Rocco \& Fava (1969) mention that - in general - laboratory breeding is characterized by a proliferation of males, which is the consequence of unfavorable trophic conditions.

As a matter of fact, it is still not known at which period the sex is definitively fixed 
and which factors control this determination in the family Tisbidae. In addition to undeniable genetic factors (Fava et al., 1976), a large number of exogenic factors intervene. Among these are: inbreeding (Battaglia, 1958; Fava \& Luparelli, 1972); delay in fertilization (Volkmann-Rocco, 1972); temperature (Ginsburger-Vogel, 1975; Gaudy et al., 1982); the population's exploitation rate (Hoppenheit, 1976); the crowding effect (Fava \& Ringoli, 1977); illumination (Moraitou-Apostolopoulou \& Dikaiakou, 1982), and food quality (Uhlig, 1983). As Uhlig (1984) very correctly remarked, it is difficult to conceive that such a large number of parameters can intervene.

In the context of the experiments carried out with the bacteria, the sex ratio is unfavorable to females in 4 out of 6 cases, and barely favorable in only 2 cases: this is in conformity with the data from the literature, but in disagreement with the results obtained with Renutryl and with the Bioter food (Gaudy \& Guérin, 1977).

\section{Parameters of population dynamics}

The net reproductive rate (Ro) is low with Helgo 21 and even lower with NCMB 308, even though mortality also was low. In fact, low mortality was a consequence of little progeny and, especially in the case of NCMB 308, of sex ratio. Comparable results, but less pronounced, were obtained with Tisbe reluctans by Volkmann-Rocco \& Fava (1969). In experiments 5 and 7 , using NCMB 13, Ro rose to a value approximately identical to that obtained previously with Renutryl (120.1: Gaudy \& Guérin, 1977) and to the mean value gained by Schwenzer (1985) at $18^{\circ} \mathrm{C}(128.2)$, but did not reach the level of 178.9 observed by Parise \& Lazzaretto (1966) with Tisbe furcata (which was T. holothuriae, according to Volkmann-Rocco, 1971). Using bacteria as food, Cuer (1983) obtained a value of 17.57 .

It is important to note that the highest value was obtained in experiment 7 , in which females developed from progeny of experiment 4 : after all, these were a F3 generation with considerable inbreeding. In Tisbe furcata from Banyuls, Battaglia (1970) observed a strong decrease of Ro between "control" (Ro $=340$ ) and "generation F1" (Ro = 54) and another decrease between F1 and F2 (Ro $=26$ ). In the present case, we observed an increase between exp. 4 and 7 , and we can conclude that trophic conditions constitute a very important factor in the life cycle of the animals; genetic inheritance is not negligible, but perhaps its importance has been overestimated under deficient trophic conditions.

Mean generation time, $T$, was highly variable between the experiments and the values appeared to be in any case higher than the values gained with artificial foods by Gaudy \& Guérin (1977), but agree very well with the results of Schwenzer (1985) and Parise \& Lazzaretto (1966): 18.85 and 18.93 days, respectively. It seems that bacteria do not provide enough of the particular components required for growth: one can see here a consequence of the use of bacteria strains without mixture (Rieper, 1978): the ratio of certain components is probably limiting. With a bacterial population obtained after addition of peptone to natural seawater, Cuer (1983) observed a very short mean generation time: 10.96 days.

Variations in specific growth rate values $(\mathrm{rm})$ were directly related to those of Ro and inversely to those of $T$. With bacteria, values of $\mathrm{rm}$ are always lower than those obtained previously, except in experiment 5 where the $\mathrm{rm}$ value $(0.263)$ is identical with the observations using TetraMin $(0.260)$, by Gaudy \& Guérin (1977) and by Cuer (1983) using 
bacteria: 0.262 . Using Helgo 21 and NCMB 308, rm is low, as a consequence of $R_{o}$ value. However, in experiments 2,6 and 7 the rm values $(0.226,0.23$ and 0.236 respectively) agree with the results of Heip (1972) for Tachidius discipes $(\mathrm{rm}=0.237)$ under laboratory conditions, but disagree with the data of Schwenzer $(1985)(\mathrm{rm}=0.257)$ and with those of Parise \& Lazzaretto (1966), $\mathrm{rm}=0.319$.

\section{CONCLUSION}

The different results obtained when supplying dried pure bacteria strains to Tisbe holothuriae show that these copepods are capable of immediately making use of two out of three proposed strains; one of the strains does not allow the obtainment of a second generation if the copepods are not supplied with food complements. Once this hurdle of physiological adaptation is passed, this latter strain is revealed to be a good food, liable to furnish a large number of descendants. These results once again demonstrate the flexibility of the species and its aptitude to make use of any alimentary substrate. The new fact is that this adaptation requires two generations, for it probably implies a complex metabolic sequence.

It must be stated that NCMB 13 could logically have been considered a very unfavorable strain, had there not been the accidental presence of TetraMin in one of the dishes, for NCMB 13 initially inhibited reproduction; yet it is seen to be a good nutrition in many respects once the adaptation barrier is overcome. This poses a fundamental question: what would have been the impact of a period of adaptation with an alimentary complement in the case of $T$. holothuriae's nutrition with Helgo 21 and NCMB 13 ? It would also be interesting to test $T$. holothuriae's possible adaptivity to other bacteria strains such as Rhodospeudomonas sp. (Rieper, 1984) which, as sole food, does not allow the obtainment of the vital cycle in the F1-generation.

One of the important points is the dissimilarity of the results obtained using different bacteria. Cuer (1983), for example, observed rather unsatisfactory results when supplying copepods with a bacteria culture obtained by enriching sea-water with peptone. As a matter of fact, if only one bacterium in a food source consisting of mixed bacteria has a deleterious effect, then the entire population can become deleterious. It would be necessary to take into account the bacteria's extracellular formations such as the presence of a capsule that releases sticky substances which are liable to trap individuals, particularly the nauplii, and which affect the final results. Lastly, it must also be considered that new bacteria can develop from the ones administered as food, thus distorting the results.

Finally, some thought should be given to the possible improvement of the copepod strain's performances (fertility, survival) by adding pure or blended bacteria strains to a given diet: the oligo-elements or molecular products comparable to vitamins or hormones would be the sole operating factors.

All these considerations show that a combined study needs to be made on the impact of bacteria communities on the population dynamics and on the physiology of Tisbe holothuriae and of other species of harpacticoids, the breeding of which could possibly be made easier by using wisely chosen bacteria.

Acknowledgements. The authors wish to thank Dr. D. Schwenzer for critically reading the manuscript, and for helpful comments and suggestions. 


\section{LITERATURE CITED}

Battaglia, B., 1957. Ricerche sul ciclo biologico di Tisbe gracilis (T. Scott), (Copepoda, Harpacticoida), studiato in condizioni di laboratorio. - Archo Oceanogr. Limnol. 11, 29-46.

Battaglia, B., 1958. Sex ratio in Tisbe gracilis, a marine copepod. - Rep. int. Congr. Zool. (Sect. 3) 15, 288-290.

Battaglia, B., 1959. Il polimorphismo adattativo e i fattori della selezione nel Copepode Tisbe reticulata Bocquet. - Archo Oceanogr. Limnol. 11, 19-69.

Battaglia, B., 1970. Cultivation of marine copepods for genetic and evolutionary research. Helgoländer wiss. Meeresunters. 20, 385-392.

Betouhim-El, T. \& Kahan, D., 1972. Tisbe pori n. sp. (Copepoda: Harpacticoida) from the Mediterranean coast of Israel and its cultivation in the laboratory. - Mar. Biol. 16, 201-209.

Brand, G. W., 1985. Effect of crowding on larval viability in Tisbe holothuriae (Copepoda: Harpacticoida). - Mar. Biol. 88, 67-72.

Brown, T. J. \& Sibert, J. R., 1977. Food of some benthic harpacticoid copepods. - J. Fish. Res. Bd Can. $34,1028-1031$.

Caumette, P., 1987. Rôle des bactéries phototrophes et des bactéries sulfato-réductrices dans les milieux lagunaires. ORSTOM, Paris, $395 \mathrm{pp}$.

Chandler, G. T., 1986. High-density culture of meiobenthic harpacticoid copepods within a muddy sediment substrate. - Can. J. Fish. aquat. Sci. 43, 53-59.

Cuer, 1., 1983. Influence du facteur trophique sur la dynamique de population de Tisbe holothuriae (Copépode Harpacticoide). Thèse Doctorat 3e cycle, Univ. Aix-Marseille, 90 pp.

Dublin, L. I. \& Lotka, A. J., 1925. On the true rate of natural increase. - J. Am. statist. Assoc. 20, 305-339.

Fava, G., Lazzaretto-Colombera, I. \& Cervelli, M., 1976. Carico genetico in Tisbe (Copepoda: Harpacticoida). II $T$. holothuriae e T. bulbisetosa della laguna di Venezia. - Atti Accad. naz. Lincei Rc. 60, 699-708.

Fava, G. \& Luparelli, R., 1972. Effetto de l'incrocio sul rapporto sessi in Tisbe clodiensis (Copepoda: Harpacticoida). - Atti Ist, veneto Sci. 130, 147-159.

Fava, G. \& Ringoli, C., 1977. Effet de la densité larvaire sur la survie chez le Copépode Harpacticoide Tisbe clodiensis. - Rapp. P.-v. Réun. Commn int. Explor. scient. Mer Méditerr. 24, 135-136.

Gaudy, R. \& Guérin, J.-P., 1977. Dynamique des populations de Tisbe holothuriae (Crustacea: copepoda) en élevage sur trois régimes artificiels différents. - Mar. Biol. 39, 137-145.

Gaudy, R. \& Guérin, J.-P., 1982. Population dynamics of Tisbe holothuriae (Copepoda; Harpacticoida) in exploited mass cultures. - Neth. J. Sea Res. 16, 208-216.

Gaudy, R., Guérin, J.-P. \& Moraitou-Apostolopoulou, M., 1982. Effect of temperature and salinity on the population dynamics of Tisbe holothuriae, Humes (Copepoda; Harpacticoida) fed on two different diets. - J. exp. mar. Biol. Ecol. 57, 257-271.

Ginsburger-Vogel, T., 1975. Température et différentiation sexuelle chez les crustacés. - Bull. Soc. zool. Fr. 100, 95-115.

Guérin, J.-P., 1971. Utilisation de nourritures artificielles pour l'élevage de jeunes stades d'invertébrés benthiques. - Tethys $2,557-566$.

Guérin, J. P., 1973. Premières données sur la longévité, le rythme de ponte et la fécondité de Scolelepis cf. fuliginosa (Polychète, Spionidé) en élevage. - Mar. Biol. 19, 27-40.

Guérin, J.-P. \& Kerambrun, P., 1982. Effects of diet on esterases, alkaline phosphatase, malate dehydrogenase and phosphoglucomutase activity observed by polyacrylamide gel electrophoresis in Tisbe holothuriae (Harpacticoid Copepod). - Comp. Biochem. Physiol. 73 B, $761-770$.

Guidi, L. D., 1984. The effect of food composition on ingestion, development, and survival of a harpacticoid copepod, Tisbe cucumariae Humes. - J. exp. mar. Biol. Ecol. 84, 101-110.

Hanaoka, H., 1973. Cultivation of three species of pelagic micro-crustacean plankton. - Bull. Plankt. Soc. Japan $20,19-29$.

Heip, C., 1972. The reproductive potential of copepods in brackish water. - Mar. Biol. 12, 219-221.

Hicks, G. R. F. \& Coull, B. C., 1983. The ecology of marine meiobenthic harpacticoid copepods. Oceanogr. mar. Biol. 21, 67-175.

Hoppenheit, M., 1975a. Zur Dynamik exploitierter Populationen von Tisbe holothuriae (Copepoda, 
Harpacticoida). I. Methoden, Verlauf der Populationsentwicklung und Einfluß der Wassererneuerung. - Helgoländer wiss. Meeresunters. 27, 235-253.

Hoppenheit, M., 1975b. Zur Dynamik exploitierter Populationen von Tisbe holothuriae (Copepoda, Harpacticoida). II. Populationsdichte, Alterszusammensetzung, Wachstum und Ausbeute. Helgoländer wiss. Meeresunters. 27, 377-395.

Hoppenheit, M., 1976. Zur Dynamik exploitierter Populationen von Tisbe holothuriae (Copepoda, Harpacticoida). III. Reproduktion, Geschlechtsverhältnis, Entwicklungsdauer und Überlebenszeit. - Helgoländer wiss. Meeresunter. 29, 109-137.

Itoh, K., 1973. Food requirements of copepods estimated from their metabolic rates. - Bull. Plankt. Soc. Japan 20, 78-83.

Johnson, M. W. \& Olson, J. B., 1948. The life history and biology of a marine harpacticoid copepod, Tisbe furcata (Baird). - Biol. Bull. mar. biol. Lab., Woods Hole 95, 320-332.

Kahan, D., 1979. Vegetables as food for marine harpacticoid copepods. - Aquaculture 16, 345-350.

Kobayashi, M. \& Kurata, S., 1978. The mass culture and cell utilization of photosynthetic bacteria. Process Biochem. 13, 27-29.

Lang, K., 1948. Monographie der Harpacticoiden. Nordiska Bokhandeln, Stockholm, 1, 1-490.

Lee, W. Y., Zhang, X. K., Baalen, C. \& von Arnold, C. R., 1985. Feeding and reproductive performance of the harpacticoid Tisbe carolinensis (Copepoda, Crustacea) in four algal cultures. - Mar. Ecol. Prog. Ser. 24, 273-279.

Lopez, G. W., 1982. Short-term population dynamics of Tisbe cucumariae (Copepoda: Harpacticoida). - Mar. Biol. 68, 333-341.

Moraitou-Apostolopoulou, M. \& Dikaiakou, N., 1982. Influence of light conditions on the offspring production and the sex-ratio of Tisbe holothuriae Humes (Copepoda, Harpacticoida). - Arch. Hydrobiol. 96, 120-127.

Parise, A. \& Lazzaretto, I., 1966. Misure di popolazione sul copepods Tisbe furcata (Baird) (Harpacticoida). - Atti Memorie Accad. patavina 79,1-11.

Provasoli, L., Shiraishi, K. \& Lance, J. R, 1959. Nutritional idiosyncrasies of Artemia and Tigriopus in monoxenic culture. - Ann. N. Y. Acad. Sci. 77, 250-261.

Provasoli, L., Conklin, D. E. \& D'Agostino, A. S., 1970. Factors inducing fertility in aseptic Crustacea. - Helgoländer wiss. Meeresunters. 20, 443-454.

Rieper, M., 1978. Bacteria as food for marine harpacticoid copepods. - Mar. Biol. 45, 337-345.

Rieper, M., 1982. Feeding preferences of marine harpacticoid copepods for various species of bacteria. - Mar. Ecol. Prog. Ser. 7, 303-307.

Rieper, M., 1984. Relationships between bacteria and marine copepods. In: Bactériologie marine. CNRS, Paris, 169-172.

Rothbard, S., 1976. Experiments in mass culture of the marine copepods Tigriopus japonicus (Mori) on a bed of crushed seaweed Ulva petrusa (Kjelman). - Bamidgeh 28-30, 80-105.

Schwenzer, D., 1985. Untersuchungen zur Produktionsbiologie von Tisbe holothuriae (Copepoda: Harpacticoidea) bei unterschiedlichen Temperatur-, Salinitäts- und Nahrungsbedingungen. Diss., Univ. Berlin, 198 pp.

Stansfield, W. D., 1981. Génétique. McGraw-Hill, Paris, 281 pp.

Uhlig, G., 1983. Massenproduktion von Lebendfutter für Marikulturzwecke. - Jber. Biol. Anst. Helgoland 1983, 76-78.

Uhlig, G., 1984. Massenproduktion von Lebendfutter für Marikultur-Systeme. - Jber. Biol. Anst. Helgoland 1984, 80-83.

Uhlig, G., 1984. Progress in mass culture of harpacticoid copepods for mariculture purposes. - Spec. Publ: Eur. Maricult Soc., 8, 261-273.

Uhlig, G. \& Schwenzer, D., 1979. Autökologische Untersuchungen an Tisbe holothuriae. Jber. Biol. Anst. Helgoland 1979, 32-35.

Uhlig, G. \& Sahling, G., 1981: Leistundsdaten eines wachstumsintensiven harpacticoiden Copepoden. - Jber. Biol. Anst. Helgoland 1981, 44-46.

Ustach, J. F., 1982. Algae, bacteria and detritus as food for the harpacticoid copepod, Heteropsyllus pseudonunni Coull and Palmer. - J. exp. mar. Biol. Ecol. 64, 203-214.

Vanden Berghe, W. \& Bergmans, M., 1981. Differential food preferences in three co-occuring species of Tisbe (Copepoda, Harpacticoida). - Mar. Ecol. Prog. Ser, 4, 213-219. 
Volkmann-Rocco, B., 1971. Some critical remarks on the taxonomy of Tisbe (Copepoda, Harpacticoida). - Crustaceana 21, 127-132.

Volkmann-Rocco, B., 1972. The effect of delayed fertilization in some species of the genus Tisbe (Copepoda, Harpacticoida). - Biol. Bull. mar. biol. Lab., Woods Hole 142, 520-529.

Volkmann-Rocco, B. \& Battaglia, B., 1972. A new case of sibling species in the genus Tisbe (Copepoda, Harpacticoida). In: Fifth European Marine Biology Symposium. Ed. by B. Battaglia. Piccin, Padova, 67-80.

Volkmann-Rocco, B. \& Fava, G., 1969. Two sibling species of Tisbe (Copepoda, Harpacticoida): Tisbe reluctans and $T$. persimilis $n$. sp. Research on their morphology and population dynamics. Mar. Biol. 3, 159-164. 